\title{
SUMBANGSIH PEMIKIRAN ETIKA JOHN FRAME DI DALAM MENGISI PENGHARAPAN MASYARAKAT KRISTEN 5.0 DI ERA REVOLUSI INDUSTRI 4.0
}

\author{
Sutjipto Subeno \\ STT Reformed Injili Internasional \\ Korespondensi: ssubeno@sttrii.ac.id
}

\begin{abstract}
The emergence of the Industrial Revolution 4.0 has led to the disruption of various fields of life, including the field of ethics. This threat of disruption initiated the hope of the formation of Society 5.0 which is expected to produce an advanced, high-tech, prosperous and moral global society. This expectation needs to be criticized, because it seems that there is not enough ethical discussion that has been elaborated in the thinking of the Society 5.0. The Christian faith (Reformed) sees the importance of ethical aspects in society, because human life cannot be separated from ethical problems and judgments. John Frame's ethical concept which has three perspectives: normative, situational, and existential, can fill this gap for every Christians to go through Industrial Revolution 4.0 era.
\end{abstract}

KEYWORDS: Etika Kristen; Teologi Reformed; Masyarakat 5.0; Masyarakat Kristen 5.0; Revolusi Industri 4.0.

ABSTRAK: Hadirnya Revolusi Industri 4.0 telah menyebabkan terjadinya berbagai disrupsi bidang kehidupan termasuk bidang etika. Ancaman disrupsi ini menggagas harapan terbentuknya Masyarakat 5.0 yang diharapkan akan menghasilkan masyarakat global yang maju, berteknologi tinggi, sejahtera dan bermoral. Harapan ini perlu dikritisi, karena terlihat kurangnya pembahasan etis yang terelaborasi di dalam pemikiran Masyarakat 5.0. Iman Kristen (Reformed) melihat pentingnya aspek etika dalam kehidupan masyarakat, karena kehidupan manusia tidak bisa terlepas dari masalah dan penilaian etis. Konsep etika John Frame yang memiliki tiga perspektif: normatif, situasional, dan eksistensial, dapat mengisi kekurangan ini di dalam perjuangan orang Kristen melalui era Revolusi Industri 4.0 ini. 
KATA KUNCI: Christian Ethics; Reformed Theology; Society 5.0; Christian Society 5.0; Industrial Revolution 4.0.

\section{Latar Belakang}

\section{Pendahuluan}

Revolusi Industri 4.0 (Industrial Revolution 4.0 / IR 4.0) ${ }^{1}$ telah menimbulkan disrupsi hampir di seluruh bidang kehidupan, tidak terkecuali bidang etika. Berlandaskan pengembangan teknologi digital dan koneksi internet secara global, IR 4.0 telah memporak-porandakan banyak kemapanan lama. Manusia terseret dan tidak siap berhadapan dengan tuntutan perubahan yang terjadi. Ditunjang oleh IoT (Internet-of-Things / Internet untuk Segala), Bigdata (Mahadata), dan AI (Artificial Intelligence / Inteligensia Buatan) menjadikan IR 4.0 mampu mengubah hampir seluruh tatanan kehidupan masyarakat. Jika dulu seseorang harus ke toko untuk membeli baju, maka sekarang dapat membelinya dari rumah berbekal telpon pintar dimana berbagai aplikasi bisa memberikan usulan baju yang kita suka, berdasarkan pengalaman kita melihat-lihat di aplikasi tersebut. Jika dulu harus antri panjang di bank untuk mengambil uang saku, kini cukup ke mesin anjungan tunai mandiri (ATM) yang sudah terkoneksi antar bank dan dalam kurang dari 2 menit uang sudah ditangan, dan begitu banyak kemudahan lain.

Pada pihak lain, muncul kesadaran adanya berbagai problema etis di dalam perkembangan IR 4.0 terhadap kehidupan manusia. Ada bahasan yang melihat adanya ancaman pelanggaran privasi, atau juga munculnya berbagai kejahatan digital dan ketidak-adilan masyarakat, atau terjadinya berbagai ketegangan sosial akibat berbagai perilaku tidak etis di dalam media sosial digital yang sudah sedemikian menyatu dengan kehidupan masyarakat.

Munculnya UU-ITE² di Indonesia berikut semua ketegangan di dalamnya, merupakan salah satu bukti permasalahan etis yang timbul akibat hadirnya media sosial digital dari IR 4.0 ini. Sigit Kurniawan, Kasubdit Identifikasi Kerentanan dan Penilaian Risiko Infrastruktur Informasi Kritikal

Perkembangan Revolusi Industri ini pertama dibahas oleh Klaus Schwab, CEO dari World Economic Forum, dan Revolusi Industri 4.0 banyak dikaitkan dengan Hannover Fair tahun 2011, dimana tahun ini dianggap sebagai awal dari Revolusi Industri 4.0. Klaus Schwab, The Fourth Industrial Revolution (New York: Penguin Random House, 2017).

UU-ITE (Undang-Undang Informasi dan Transaksi Elektronik) merupakan produk hukum untuk melindungi kepentingan hukum negara dan rakyat Indonesia dari kejahatan elektronik (digital) sebagai akibat dari perkembangan teknologi informasi yang begitu cepat. Undang-Undang ini pertama kali diterbitkan pada 21 April 2008 dan mengalami berbagai revisi hingga hari ini. (“Undang-Undang Informasi dan Transaksi Elektronik", Wikipedia, modifikasi terakhir pada 6 Agustus 2021, 12:13, https://id.wikipedia.org/wiki/Undang-Undang_Informasi_dan_Transaksi_Elektronik). 
Nasional III BSSN, menyatakan bahwa "Saat pandemi, orang-orang makin sering transaksi digital. Kenaikan transaksi digital memicu para penjahat makin banyak," secara statistik serangan siber (kejahatan digital) meningkat empat kali lipat dari sebelum pandemi, dari sekitar 39 juta menjadi 190 juta tindak kriminal digital. ${ }^{3}$ Berbagai media juga memberitakan permasalahan privasi dimana bocornya data-data rahasia pribadi yang tidak seharusnya diakses oleh orang yang tidak tepat dan dapat menimbulkan dampak kejahatan sosial dan ekonomi. Di atas semua itu, ada hal yang lebih dikhawatirkan, yaitu ketika kekuatan IR 4.0 ini telah berkembang sedemikian kuat dan menjadi tiran yang mengatur seluruh kehidupan masyarakat. ${ }^{4} \mathrm{Hal}$ ini diperkirakan akan menjadi semakin kompleks dengan peran Inteligensia Buatan yang diupayakan mengambil alih peran otak manusia, termasuk tentunya berbagai pertimbangan etis di dalamnya.

Jepang, sebagai negara yang sedemikian maju di dalam bidang teknologi digital, sangat menyadari adanya bahaya IR 4.0 terhadap kehidupan masyarakatnya jika tidak segera mengambil langkah untuk mengantisipasi perubahan yang terjadi. Satu team penggagas dari kantor kementerian Jepang mengembangkan apa yang dinamakan Society 5.0 (Masyarakat 5.0). ${ }^{5}$ Diharapkan dengan gagasan dan proses yang digarap, maka Jepang dan dunia akan mampu menghadirkan suatu masyarakat masa depan yang sejahtera dengan menyelaraskan dunia maya (cyberspace) dengan dunia fisik (real space). Harapan akhirnya adalah terbentuk satu masyarakat yang mampu mengatasi berbagai masalah sosial di dalamnya, seperti yang juga disimpulkan oleh pemrasaran pikiran ini di Indonesia, Halifa Haqqi. Ia menuliskan: "Masyarakat 5.0 merupakan sebuah konsep yang berupaya memberikan kehidupan yang lebih baik bagi manusia. Tidak sekedar lebih baik dari fasilitas teknologi yang bisa dimanfaatkan di sekitar manusia, melainkan juga lebih baik dari sisi nilai dan moral dalam menjalankan kebermanfaatan kehidupan." ${ }^{6}$

Di dalam pembahasan Masyarakat 5.0 baik dari Kabinet Pemerintahan Jepang maupun dalam buku Halifa Haqqi terungkap

\footnotetext{
Putri Zakia Salsabila, "Kejahatan Siber di Indonesia Naik 4 Kali Lipat Selama Pandemi", Kompas.com, 12 Oktober 2020, https://tekno.kompas.com/read/2020/10/12/07020007/ kejahatan-siber-di-indonesia-naik-4-kali-lipat-selama-pandemi.

4 Telah banyak pembahasan, walaupun sebagian orang menganggap sebagai fiksi, namun kekuatan Mahadata di dalam kehidupan masyarakat sudah dirasakan mulai mendikte berbagai perilaku manusia. Hal ini kemudian dikenal sebagai “Dataisme." (Steven Parton, "The Rise of Dataism: A Threat to Freedom or a Scientific Revolution?", SingularityHub, modifikasi terakhir pada 30 September 2018, https://singularityhub. com/2018/09/30/the-rise-of-dataism-a-threat-to-freedom-or-a-scientific-revolution/).

“Society 5.0", Cabinet Office Japan, diakses pada 29 Juli 2021, https://www8.cao.go.jp/cstp/ english/ society5_0/index.html.

6 Halifa Haqqi dan Hasna Wijayati, Revolusi Industri 4.0 di tengah Society 5.0 (Yogyakarta: Penerbit Quadrant, 2019), 181.
} 
adanya harapan terbentuknya suatu kehidupan masyarakat yang baik dan sejahtera. Masyarakat baik tentunya tidak terlepas dari adanya aspek etis dalam kehidupan masyarakat tersebut. Namun, tidak terlihat landasan etis yang dibangun di dalam gagasan Masyarakat 5.0 Ini. Akibatnya, apa yang diharapkan Masyarakat 5.0 dapat berdampak sebaliknya. Pemikiran ini menjadi lebih serius di dalam pandangan Kristen. Tidak mungkin satu bentukan masyarakat akan menjadi baik dan sejahtera tanpa melibatkan elemen etis di dalamnya. Disini pentingnya sumbangsih pemikiran John Frame mengisi kekosongan landasan etis bagi pemikiran Masyarakat 5.0.

Berdasarkan hal di atas, makalah ini mencoba untuk menjawab dua permasalahan, yaitu:

1. Apakah Masyarakat 5.0 (Society 5.0) dapat mencapai tujuan yang diharapkan?

2. Bagaimana Etika Kristen yang ditawarkan oleh John Frame dapat mengisi kekurangan dari gagasan Masyarakat 5.0?

Pemikiran tentang Masyarakat 5.0 digagas oleh kementerian pemerintah Jepang, ketika mereka melihat pengembangan Masyarakat 4.0 (masyarakat informasi) cenderung dikuasai oleh kekuatan IR 4.0. Pemikiran Masyarakat 5.0 dirancang dan diuraikan di dalam website resmi kementerian Jepang. ${ }^{7}$ Dan pembahasan Masyarakat 5.0 mendapatkan slot khusus dalam website resmi pemerintah ini. ${ }^{8}$ Pemikiran dan gagasan yang dianggap sangat penting dan bersifat menerobos ini segera juga direspon oleh Japan Business Federation - Keidanren dengan segera mengupayakan langkah-langkah antisitpatif dan aplikatif dari Masyarakat 5.0 ini. ${ }^{9}$ Masyarakat 5.0 (Society 5.0) dipaparkan sebagai berikut:

One definition: "A human-centered society that balances economic advancement with the resolution of social problems by a system that highly integrates cyberspace and physical space."

Society 5.0 was proposed in the 5th Science and Technology Basic Plan as a future society that Japan should aspire to. It follows the hunting society (Society 1.0), agricultural society (Society 2.0), industrial society (Society 3.0), and information society (Society 4.0). ${ }^{10}$

Inovasi yang diharapkan melalui Masyarakat 5.0 akan dapat menerobos semua stagnasi yang kini terjadi, hingga tercapai masyarakat yang: 1) semangat saling menghormati dan menghargai satu terhadap yang lain,

the Cabinet Office home page (https://www.cao.go.jp/).

Cabinet Office Japan, "Society 5.0".

Keidanren, Toward Realization of the New Economy and Society (Japan: Japan Business Federation, 2016), http://www.keidanren.or.jp/en/policy/2016/029_outline.pdf.

10 Keidanren, Toward Realization. 
yang melampaui batasan generasi (aspek sosial); 2) setiap pribadi dapat mengarah dan menikmati hidup yang aktif dan menyenangkan (aspek kesejahteraan). Inilah sasaran akhir Masyarakat 5.0.

John Frame, di dalam buku The Doctrine of the Christian Life, ${ }^{11}$ membangun satu pemikiran etis yang diharapkan bisa mengantisipasi perkembangan sejarah, perubahan tatanan masyarakat, dan timbulnya berbagai kondisi pribadi dan masyarakat, tanpa kehilangan dasar pijak normatif, yaitu Allah dan firman-Nya. Frame melihat bahwa seluruh teologi dan kehidupan Kristen adalah urusan etika. ${ }^{12}$ Etika Kristen yang mampu menghadapi dan mengatasi permasalahan etis di era IR 4.0 harus memiliki dasar yang kuat dan kokoh secara universal (perspektif normatif), namun pada pihak lain memiliki kemampuan dinamis untuk dapat diaplikasikan di dalam situasi dan kondisi tertentu (perspektif situasional), dan juga bisa melihat sampai kepada aspek yang internal, yaitu aspek tujuan dan motif dari tindakan etis tersebut (perspektif eksistensial).

\section{Metodologi}

Pembahasan makalah didasarkan pada riset literatur dan beberapa media audio visual. Studi literatur diutamakan menyoroti topik: etika, etika Kristen Reformed, Society 5.0 (masyarakat 5.0), Industrial Revolution 4.0 (Revolusi Industri 4.0), Dataisme dan Agama Data. Tinjauan ini dilakukan berdasarkan pendekatan dan landasan Alkitab dalam kerangka pikir Theologi Reformed. Makalah tidak membahas kekuatan komprehensivitas Theologi Reformed di dalam mengungkapkan kebenaran Alkitab dan juga di dalam menggarap Mandat Budaya, namun pendekatan ini diperlukan agar kritik yang dilakukan memiliki landasan pijak yang bisa dipertanggung jawabkan. ${ }^{13}$

\section{Alur Pemikiran}

Diawali dengan menyoroti perkembangan IR 4.0 yang memiliki karakteristik yang sangat berbeda dari Revolusi Industri sebelumnya. IR 4.0 merupakan suatu revolusi yang berkembang sedemikian cepat dan dahsyat yang belum pernah terjadi sebelumnya. Perkembangan dunia internet begitu cepat. IR 4.0 adalah revolusi global yang menyentuh seluruh dunia dari kota besar

\footnotetext{
11 John Frame, The Doctrine of the Christian Life (A Theology of Lordship) (Phillipsburg, New Jersey: P\&R Publishing, 2008)

12 Frame, The Doctrine of the Christian Life, 1.

13 Tentang pemikiran Theologi Reformed, dapat melihat sangat banyak sumber literatur, di antaranya: Joel R. Beeke dan Paul M. Smalley, "10 Things You Should Know About Reformed Theology", Crossway, 14 April 2019, https://www.crossway.org/articles/10-things-you-should-know-about-reformedtheology-2; Loraine Boettner, Studies in Theology (Phillipsburg, NJ.: P\&R Publishing, 1984); Herman Bavinck, Reformed Dogmatics (4 vols) (Grand Rapids, Mi.: Baker Academic, 1984).
} 
dan terus merangsak hingga ke pelosok-pelosok.

Pengembangan IR 4.0 memberikan dampak yang besar yang positif di banyak aspek kehidupan. Banyak kemudahan dinikmati dengan adanya pengembangan dan kecepatan informasi global. Kemampuan pengembangan Bigdata dan Inteligensia Buatan sudah mencapai tingkat yang begitu kompleks dan bisa sangat banyak memberi sumbangsih baik di dunia pendidikan, sosial, ekonomi, medis dan berbagai hal lain. Statistik menunjukkan bahwa di kwartal kedua tahun 2020 sudah sekitar 70\% populasi Indonesia menggunakan internet. ${ }^{14}$ Statistik ini tentunya akan terus meningkat bukan hanya secara kuantitas, tetapi juga secara kualitas penggunaan, sehingga akan menjadi sumbangsih besar bagi Mahadata dan kekuatan Inteligensia Buatan di Indonesia di masa mendatang.

Di balik dampak positif dari IR 4.0 ada sisi lain dari keping koin pengembangan teknologi digital ini. Adanya berbagai tuntutan masalah privasi informasi yang sulit dijaga, masalah perilaku-perilaku yang tidak etis di dalam penggunaan media sosial, dan juga kejahatan-kejahatan siber yang begitu marak terjadi, telah menjadi topik pembahasan media, baik dari aspek sosial dan hukum. ${ }^{15}$ Ini adalah problema etis yang terjadi mengikuti pengembangan IR 4.0

\section{Pentingnya Etika Kristen dan Pemikiran Etika John Frame}

Salah satu aspek sosial yang penting melandasi kehidupan bermasyarakat adalah etika. Etika adalah suatu norma atau aturan yang dipakai sebagai pedoman dalam berperilaku di masyarakat bagi seseorang terkait dengan sifat baik dan buruk. ${ }^{16} \mathrm{KBBI}$ memberikan definisi: ilmu tentang apa yang baik dan apa yang buruk dan tentang hak dan kewajiban moral (akhlak). Suatu masyarakat akan dapat menjadi masyarakat yang dapat berelasi baik satu dengan yang lain, sejahtera, dan memiliki kehidupan moralitas pribadi yang baik. Dari sejak Socrates hingga saat ini, disadari bahwa kehidupan relasi yang baik di dalam masyarakat tidak bisa dilepaskan dari pertimbangan dan tindak etis dari pribadi-pribadi yang ada di dalam masyarakat tersebut.

\footnotetext{
14 First Media, "Artificial Intelligence - Dampak, Tantangan dan Manfaat dalam Bisnis", Firstmedia.com, modifikasi terakhir pada 19 Januari 2021, https://www.firstmedia.com/article/ artificial-intelligence-dampak-tantangan-dan-manfaat-dalam-bisnis.

15 Ani Mardatila, "12 Jenis-Jenis Cyber Crime atau Kejahatan Dunia Maya yang Perlu Diwaspadai", Merdeka.com, 26 November 2020, https:/www.merdeka.com/sumut/12-jenis-jenis-cyber-crime-atau-kejahatan-dunia-maya-yang-perlu-diwaspadai-kln.html.

16 Tautan untuk lebih melihat keragaman masalah etika dapat melihat: Aris Kurniawan, "Pengertian Etika - Fungsi, Manfaat, Macam, Perbedaan, Contoh, Para Ahli", Gurupendidikan.com, modifikasi terakhir pada 20 Agustus 2021, https://www.gurupendidikan.co.id/pengertian-etika/.
} 
Berbagai teori etika telah banyak dikemukakan, baik dalam aspek landasan pikirnya, seperti Etika Normatif dalam Nichomachean Ethics-nya Aristoteles, ${ }_{17}^{17}$ Etika Deontologi dari Immanuel Kant, ${ }^{18}$ Etika Utilitarian dari Jeremy Bentham, ${ }^{19}$ Etika Situasi dari Joseph Fletcher, ${ }^{20}$ dll. Etika juga dapat dilihat dari pandangan praktikanya, seperti etika normatif, meta-etika, ataupun etika terapan. ${ }^{21}$ Dari berbagai teori etika ini, maka pemikiran dari John Frame dapat dipandang mewakili pemikiran etika Kristen Reformed.

John Frame (1939 - ), seorang pemikir dan profesor Reformed yang sangat produktif. ${ }^{22}$ Ia mencurahkan pemikirannya bagi relevansi Theologi Reformed di tengah-tengah perkembangan zaman dan tantangan masa kini. Dia menulis belasan buku, dan banyak artikel, khususnya di bidang Apologetika dan Etika. Ia menulis etika medis, ${ }^{23}$ dan juga prinsip etika Kristen di dalam bukunya The Doctrine of the Christian Life. ${ }^{24}$ Pembahasan etika di dalam buku ini cukup komprehensif.

John Frame menyatakan bahwa etika bukan sekedar sebuah wacana atau ilmu teoritis belaka, tetapi merupakan totalitas dari seluruh kehidupan Kristen itu sendiri. ${ }^{25}$ Hidup Kristen adalah hidup etis. Frame menjelaskan bahwa etika dunia sekuler berbeda dengan etika Kristen yang dilandaskan pada Alkitab. John Murray mengungkapkan etika sebagai prinsip tingkah laku (principles of conduct) yang seharusnya sesuai dengan kebenaran Allah. John Frame, mengikuti John Calvin dan Cornelius Van Til, menyatakan bahwa etika adalah totalitas teologi dan kehidupan, yang merupakan Implementasi dari kehidupan yang dipersekutukan dengan Kristus (union with Christ). Frame menegaskan bahwa "everything in the Bible is ethical."26 Inilah landasan penting bangunan etika Kristen yang ditegakkan oleh

17 Richard Kraut, "Aristotle's Ethics", The Stanford Encyclopedia of Philosophy (Summer 2018 Edition), diakses pada 12 Agustus 2021, https://plato.stanford.edu/entries/aristotle-ethics/.

18 Larry Alexander dan Michael Moore, "Deontological Ethics", The Stanford Encyclopedia of Philosophy (Summer 2021 Edition), diakses pada 12 Agustus 2021, https://plato.stanford.edu/entries/ ethics-deontological/.

19 Julia Driver, "History of Utilitarianism", The Stanford Encyclopedia of Philosophy (Winter 2014 Edition), diakses pada 12 Agustus 2021, https://plato.stanford.edu/entries/utilitarianism-history/.

20 Sandra B. Rosenthal, "Situation ethics", Encyclopedia Britannica, diakses pada 12 Agustus 2021, https://www.britannica.com/topic/situation-ethics.

21 Steve McCartney dan Rick Parent, Ethics in Law Enforcement (Victoria, B.C.: BCcampus, 2015), chap. 2.1, https://opentextbc.ca/ethicsinlawenforcement/chapter/2-1-major-ethical-systems/.

22 John M. Frame, profesor Systematic Theology di Westminster Theological Seminary dan emiritus profesor dari Reformed Theological Seminary. Lulusan Princeton Universty (B.A.), Westminster Theological Seminary (B.Div.), dan Yale University (M.A., M.Phil.). Frame mendapatkan Doktor Honoris Causa dari Belhaven College.

23 John M. Frame, Medical Ethics: Principles, Persons, and Problems (Phillipsburg, NJ.: P\&R Publishing, 1988).

24 John M. Frame, The Doctrine of the Christian Life.

25 Frame, 1.

26 John M. Frame, The Doctrine of the Christian Life, 4. 
kebanyakan teolog Reformed. Keunikan etika John M. Frame adalah upaya untuk melihat etika sebagai sesuatu yang memiliki dasar dan prinsip yang mutlak, namun juga harus mempertimbangkan berbagai aspek dinamis dalam kehidupan. Untuk itu, ia menegakkan tiga perspektif untuk membangun etika Kristen yang dapat bertahan di tengah dinamika sejarah dunia. ${ }^{27}$

a. Perspektif Normatif (Hidup di bawah Hukum Allah). Dunia etika masa kini kesulitan membangun landasan normatif yang absolut akibat menolak firman Tuhan sebagai wahyu kebenaran yang sejati. Ketika manusia mencoba membangun landasan etika obyektif, seperti yang diupayakan Kant, kondisi obyektif yang diharapkan tidak pernah bisa terbentuk. Manusia hidup, suka atau tidak suka, harus tunduk atau memilih memberontak terhadap hukum dan pengaturan Allah. Pertimbangan untuk taat atau memberontak ini merupakan hakekat dari pertimbangan etis manusia tersebut. Oleh karena itu, diperlukan landasan normatif yang absolut sebagai landasan atau dasar pertimbangan etis seseorang. Sebagai pondasi absolut, Firman Allah harus menjadi landasan normatif bagi seluruh kehidupan manusia.

b. Perspektif Situasional (Hidup dalam Dunia milik Allah). Prinsip normatif etika Kristen perlu diterapkan di dalam dunia yang bersifat pluralistik. Dunia dimana manusia hidup bukanlah dunia yang seragam, statis, dan absolut. Dunia kehidupan adalah dunia yang berbeda di setiap daerah, berubah seiring perjalanan waktu, dan dipengaruhi oleh banyak faktor. Prinsip etika normatif yang absolut harus mampu terimplementasi di dalam kondisi yang berbeda-beda. Disini Frame melihat pentingnya melihat bahwa manusia hidup di dalam dunia milik Allah, bukan milik manusia atau tanpa kepemilikan. Maka pertimbangan etis harus senantiasa mampu beradaptasi dengan pergerakan zaman, menghadapi berbagai hal yang dulu belum pernah ada di zaman Alkitab.

c. Perspektif Eksistensial (Hidup di hadapan Allah). Pergumulan pilihan dan keputusan etis juga tidak lepas dari subyektivitas pelakunya. Manusia secara individu hidup di dalam konteksnya. Disana pertimbangan etis tidak lepas dari motivasi yang melandasi pemikirannya. Dalam pandangan Kristen disinilah aspek subyek perlu direlasikan dengan elemen normatif dan situasional. Perspektif motivasional ini merupakan pertanggung-jawaban etis seseorang, bukan dihadapan manusia, tetapi di hadapan Allah secara pribadi dan eksistensial. Frame melihat hal ini sebagai perspektif eksistensial. Frame menekankan bahwa di dalam pandangan Kristen, dan tentunya semua manusia seharusnya berpikir sama, bahwa Allah yang 
menuliskan hukum-Nya ke dalam hati nurani manusia, Dia adalah Hakim dan Diri Kebajikan itu sendiri. Baik tidak bisa lepas dari diri Allah yang adalah Diri Kebajikan dan standar kebajikan. Manusia baik dan sejahtera bukan di dalam penilaian diri, tetapi di dalam penilaian Allah. ${ }^{28}$ Setiap manusia harus mempertanggung-jawabkan perbuatan baiknya di hadapan Allah dengan mentaati norma yang Allah tetapkan dan bermotivasi ingin hidup berkenan di hadapan Allah.

\section{Gagasan Masyarakat 5.0 di Era Revolusi Industri 4.0}

Masyarakat 5.0 adalah "A human-centered society that balances economic advancement with the resolution of social problems by a system that highly integrates cyberspace and physical space." Masyarakat 5.0 adalah satu bentukan satu kehidupan masyarakat yang berpusat pada manusia. Penekanan ini untuk mengantisipasi upaya tekanan IR 4.0 dimana kehidupan dipusatkan pada kepentingan mesin dan Inteligensia Buatan. Seluruh pengembangan teknologi harus berpusat demi kesejahteraan dan kebaikan manusia.

\section{Kaitan Revolusi Industri 4.0 dan Masyarakat 5.0}

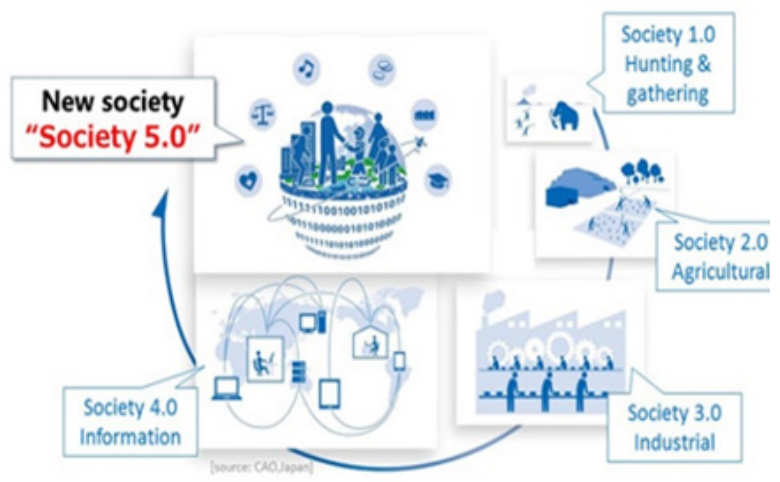

Gambar 1 - Perkembangan Masyarakat dari 1.0 hingga 5.0

Masyarakat 5.0 adalah tahap kelima dari empat tahap kehidupan masyarakat yang digambarkan sebagai: 1) masyarakat berburu (hunting society), 2) masyarakat bertani (agricultural society), 3) masyarakat industri (industrial society); 4) masyarakat informasi (informational society), dan kini mereka mengembangkan new social reformed society (masyarakat pembentuk sosial baru). ${ }^{29}$

28 John M. Frame, The Doctrine of the Christian Life, 325.

29 Cabinet Office Japan, "Society 5.0". 
Seiring dengan pengembangan Era Revolusi Industri 4.0 maka berkembang pula Masyarakat 4.0, yang juga disebut sebagai Masyarakat Informasi. Masyarakat 4.0 memiliki beberapa karakteristik antara lain:

a) Masyarakat yang hidup dengan internet, mengandalkan pelayanan dari internet awan (cloud) dan mengakses data demi kepentingan untuk menganalisa informasi. Maka, disini manusia harus bekerja demi data.

b) Masyarakat yang hidup dikendalikan dan diatur gerak oleh sistim komputer atau internet, dimana manusia mengikuti perkembangan perintah dari sistim yang mengatur tata kerja manusia.

c) Robot-robot bekerja berdasarkan perintah dari manusia, diatur dan digerakkan oleh manusia. Disini manusia akhirnya yang harus memikirkan dan bekerja agar robot-robot itu bekerja dengan benar.

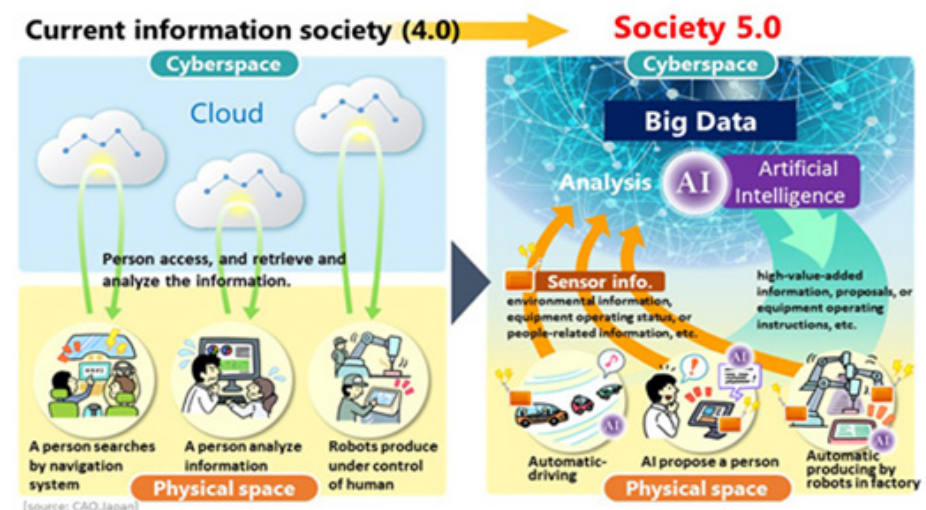

Gambar 2 - Perbedaan Masyarakat 4.0 dan Masyarakat 5.0

Pada hakekatnya, kita melihat bahwa Internet dan Awan (cloud) merupakan sumber data dan informasi, dimana manusia mengakses, menganalisa, dan mengerjakan apa yang diinformasikan oleh internet.

Masyarakat 5.0 berusaha untuk mencapai beberapa hal yang dipandang bermasalah pada Masyarakat 4.0 yang terjadi akibat Revolusi Industri 4.0. Di dalam Masyarakat 4.0 pusat berada pada Internet (Dunia Siber / Cyberspace), sedangkan manusia menjadi alat dari kepentingan dunia siber tersebut. Masyarakat 5.0 berharap yang terjadi adalah sebaliknya. Manusia harus menjadi pusat dan dilayani oleh dunia siber dan internet. Masyarakat 5.0 adalah masyarakat dimana manusia menikmati pelayanan dari internet dan menggunakannya untuk kepentingan manusia. Dari ilustrasi pada Gambar 2 terlihat jelas apa yang menjadi pemikiran Masyarakat 5.0.

Masyarakat 5.0 adalah masyarakat dimana Internet dan Dunia Siber tidak perlu diakses langsung oleh manusia, dimana manusia harus 
bersusah payah melakukan pencarian dan pengambilan informasi, pengolahan informasi, dan upaya aplikasi informasi. Semua ini akan dikerjakan oleh Mahadata (Bigdata) dan Inteligensia Buatan (Artificial Intelligence). Pertimbangan, pemikiran, dan hasil diberikan oleh Inteligensia Buatatn kepada manusia untuk dinikmati. Disini manusia betul-betul akan menjadi masyarakat dimana teknologi melayani manusia.

\section{Harapan Masyarakat 5.0}

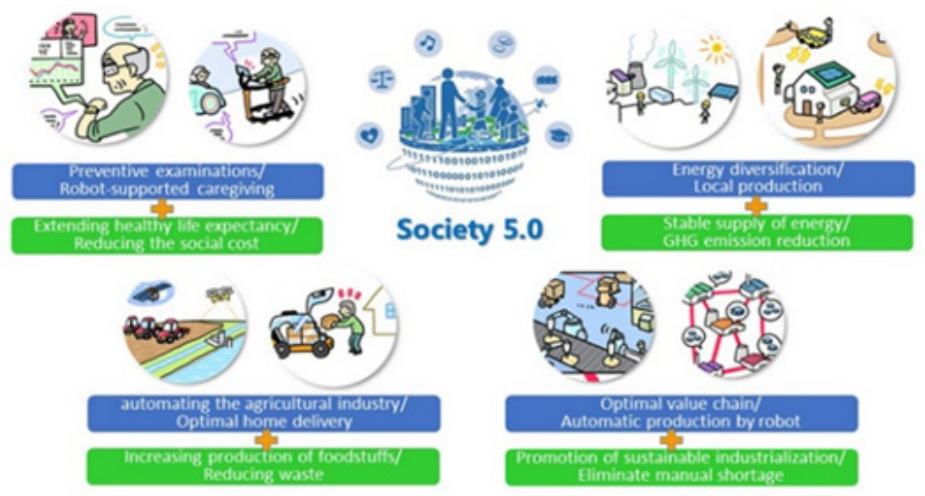

Gambar 4 - Harapan Ekonomi \& Sosial Masyarakat 5.0

Seluruh gagasan Masyarakat 5.0 pada puncaknya mengharapkan ada dua ujung tombak yang akan dicapai, yaitu: 1) Pengembangan Ekonomi yang Kokoh; dan 2) Solusi terhadap Permasalahan Sosial. Untuk mencapai dua sasaran utama ini, ada empat hal yang diharapkan dapat menjadi penunjang keberhasilannya, yaitu: ${ }^{30}$

1) Penggunaan robot di dalam pelayanan medis dan juga dukungan kemampuan inteligensia buatan, akan membantu terjadinya perluasan kemampuan pelayanan kesehatan masyarakat dengan biaya yang lebih murah. Diharapkan akan banyak pelayanan medis yang tidak lagi mengandalkan pekerjaan manusia (yang relatif mahal dan kurang akurat).

2) Kemampuan bigdata dan inteligensia buatan juga akan mengendalikan efisiensi penggunaan energi, melakukan analisa yang akurat dan pada akhirnya memberikan kestabilan tersedianya energi dengan pengurangan dampak emisi rumah kaca (GHG emission).

3) Peningkatan penyediaan industri agrikultur dengan bantuan bigdata dan analisa inteligensia buatan untuk menghasilkan hasil bumi dan

30 Cabinet Office Japan, “Society 5.0". 
sumber daya pangan yang lebih tepat dengan memperbandingkan berbagai elemen dan variabel pertanian dan peternakan, sehingga akan didapatkan ketahanan ketersediaan pangan dan pengurangan sampah secara maksimal.

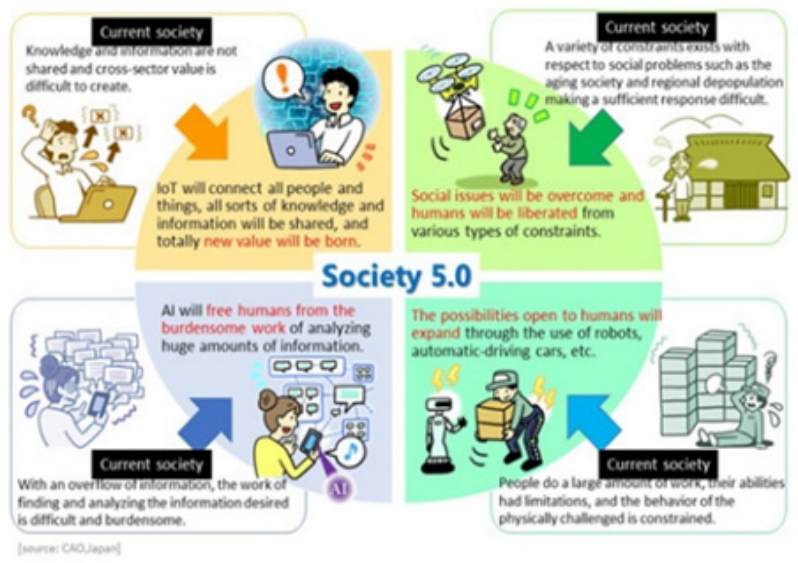

Gambar 3 - Harapan Masyarakat 5.0

4) Pengolahan data dan inteligensia buatan akan melakukan analisa dan pengembangan penggunaan robot di berbagai industri yang dikendalikan secara lebih efisien dan akurat oleh inteligensia buatan, sehingga akan menghasilkan produksi yang lebih bermutu, lebih cepat, dan lebih murah. Pada akhirnya akan dicapai suatu industri yang semakin bisa ramah lingkungan, bisa semakin bertahan di tengah berbagai goncangan ekonomi.

Diharapkan melalui empat aspek utama di atas akan terbentuk masyarakat yang sejahtera secara ekonomi, mengalami pertumbuhan ekonomi yang baik, dan akan mengurangi munculnya berbagai problema sosial.

\section{Etika dalam Gagasan Masyarakat 5.0}

\section{Keniscayaan Etika dalam Masyarakat}

Sangatlah jelas bahwa Masyarakat 5.0 berkeinginan manusia dapat membentuk suatu masyarakat (society) yang baik dan sejahtera, bukan hanya untuk negara Jepang, tetapi juga mendunia. Ini adalah sebuah harapan global yang positif. Hal ini terlihat dari sasaran yang ingin dicapai, yaitu: "Achieving Society 5.0 with these attributes would enable not just Japan but the world as well to realize economic development while solving key social problems." 31 Baik dan sejahtera di dalam Masyarakat 5.0 diterjemahkan sebagai: a) sejahtera secara ekonomis, dan b) hidup bersama tanpa atau sedikit masalah sosial. 
Masalah kesejahteraan ekonomis sementara kita kesampingkan, karena tidak terkait langsung dengan tema etika di dalam makalah ini, tetapi solusi terhadap problema sosial tidaklah bisa dilepaskan dari masalah etika. ${ }^{32}$ Kerinduan adanya kehidupan sosial yang baik tidak lain adalah kerinduan etis. Disini diupayakan terselesaikannya berbagai permasalahan sosial.

Namun, perhatian permasalahan sosial di dalam Revolusi Industri 4.0 diarahkan lebih kepada problematika ekonomis. Dalam makalahnya, Violeta Sima dkk. melihat permasalahan sosial bukan dari aspek etis, tetapi lebih melihatnya dari aspek ketakutan masyarakat berhadapan dengan transformasi teknologi yang begitu cepat, kehilangan pekerjaan, seperti tulisannya: "At this current stage, the economic-social transformations do not have their roots in discovering a new form of energy, but they are based on the latest technological phenomenon-digitalization." ${ }^{\prime 33}$ Hal ini juga terlihat di dalam pembahasan Haqqi, sekalipun tersebutkan di dalam pemikiran harapan Masyarakat 5.0, tetapi tidak terlihat dibahas dengan tuntas di dalam bukunya. Ia hanya menuliskan:

"Masyarakat 5.0 adalah konsep idaman yang dianggap mampu menghadirkan kerekatan antar-manusia sehingga satu sama lain dapat saling menghormati. Masing-masing individu diharap mampu memimpin kehidupannya sendiri yang aktif dan menyenangkan." ${ }^{34}$

Sekalipun dipaparkan bagaimana diharapkan ada relasi sosial yang baik, namun pembahasan selanjutnya, sama sekali tidak terlihat ada pembahasan etis didalam upaya pencapaian relasi antarmanusia yang baik, dan saling menghormati tersebut. Terdapat kesan, seakan dengan pemberesan masalah teknologi dan ekonomi, dengan sendirinya masalah sosial akan terselesaikan dan akan terbentuk masyarakat yang aktif, menyenangkan secara individu dan dapat saling menghormati satu terhadap yang lain. Ada kesan problema sosial hanyalah problema teknologi dan ekonomi, tanpa mempedulikan adanya pluralitas individu, isu religius, dan isu etis dalam relasi sosial antar manusia.

\section{Problema Etis Masyarakat 5.0}

Dalam lensa sosial Masyarakat 5.0 problema psikologis, problema kejahatan dan problema hukum akan terselesaikan ketika seluruh kerumitan

32 Seperti diungkap di awal makalah, isu etika atau prinsip berperilaku adalah upaya menata relasi sosial untuk mengurangi atau meniadakan terjadinya berbagai masalah sosial. Dengan kata lain, problema etika adalah problema sosial.

33 Violeta Sima et al., "Influences of the Industry 4.0 Revolution on the Human Capital Development and Consumer Behavior: A Systematic Review," Sustainability 12, no. 10 (14 Mei 2020): 4035, https://doi. org/ 10.3390/su12104035.

34 Haqqi dan Wijayati, Revolusi Industri 4.0 di tengah Society 5.0, 171. 
masyarakat diambil alih oleh Mahadata dan Inteligensia Buatan. Adanya asumsi bahwa dengan kekuatan Inteligensia Buatan, maka berbagai pertimbangan etis akan terselesaikan dengan obyektivitas pertimbangan yang dikerjakan oleh mesin. Kekuatan data dan "otak buatan" akan menggantikan kesulitan etis manusia. Tidak perlu ada perseteruan, karena penentuan yang mana yang baik tidak lagi diperdebatkan oleh dua pihak, tetapi diambil alih secara obyektif oleh Inteligensia Buatan, manusia tinggal menggunakan atau menjalankannya.

Asumsi Masyarakat 5.0 yang melihat bahwa dengan kekuatan Mahadata dan Inteligensia Buatan mampu memberikan jawaban etis dalam kehidupan sosial masyarakat perlu kita kritisi dari beberapa aspek.

a) Menon-manusiakan Manusia. Jika inteligensia buatan berhasil mengambil alih semua perdebatan dan pertimbangan etis manusia, maka itu sebenarnya melawan harapan dari Masyarakat 5.0 itu sendiri, yang ingin memanusiakan manusia dan menjadikan manusia sebagai pusat dari pergerakan. Manusia yang tidak lagi bisa memberikan dan mengambil keputusan etis, dituntut pertanggung-jawaban etis kepadanya, sudah bukan manusia lagi. Ketika mobil Anda dikendalikan oleh Inteligensia Buatan, dan mobil Anda menabrak mati seseorang, sementara Anda tidak bisa mengambil keputusan etis terhadap keadaan tersebut, karena keputusan ditentukan oleh Mahadata dan Inteligensia Buatan dari mobil Anda, maka pada hakikatnya Anda sudah bukan manusia lagi. Menunjang kemanusiaan tidak dapat digantikan dengan mengambil alih kebijakan dan keputusan etis manusia, karena justru itu merupakan tindak menon-manusiakan manusia sebagai makhluk etis. Agus Sudibyo dalam artikelnya berupaya mengangkat masalah etis akibat Inteligensia Buatan..$^{35}$

b) Matinya Relasi Antarmanusia. Jika seluruh relasi antarmanusia dimediasi oleh Mahadata dan inteligensia buatan, maka yang terjadi adalah hilangnya kemanusiaan. Benar, dengan kekuatan Mahadata dan Inteligensia Buatan relasi antarmanusia bisa dibuat sedemikian obyektif dengan berbagai pertimbangan global yang canggih, kompleks, dan akurat, sehingga tidak dapat dipersalahkan, tetapi pada saat yang sama akal budi manusia saat itu sudah dimatikan. Manusia akan berelasi dengan sesamanya seperti dua buah mesin yang bekerja bersama.

35 Agus Sudibyo, "Menggugat Monopoli Platform Digital”, Kompas.id, 08 Juli 2020, https:// www.kompas. id/baca/opini/2021/07/08/menggugat-monopoli-platform-digital/; Agus Sudibyo, "Mempersoalkan Imparsialitas Platform Digital", Kompas.id, 23 September 2021, https://www.kompas.id/ baca/opini/2021/09/23/demitologi-imparsialitas-platform-digital/. 
c) Kesulitan Menghadapi Isu Pluralitas. Masyarakat 5.0 terlihat aman dimana manusia sudah berpikir homogen. Namun, secara hakekat, manusia adalah makhluk sosial-religius, dimana terdapat pluralisme ras, suku, agama, dan kepercayaan. Khususnya kondisi di bumi Indonesia sangat berbeda dengan kondisi di Jepang. Kekuatan Inteligensia Buatan tidak mampu menjangkau permasalahan perbedaan iman kepercayaan yang menjadi landasan tindak etis, ataupun perbedaan budaya dan kebiasaan suku, ras, dan pemikiran individu yang akan mempengaruhi pertimbangan dan tindak etis seseorang.

Disini pemikiran Kristen (Reformed) melihat pemikiran etis dari John Frame sangat dibutuhkan di dalam penggarapan Masyarakat 5.0 ini untuk menjadikan manusia itu manusia dan khususnya manusia etis yang bertanggung jawab di dalam berelasi dengan sesamanya, saling menghormati, dan terlebih lagi, saling mengasihi dan bahkan saling berkorban demi kebaikan orang lain, seperti yang diteladankan oleh Tuhan Yesus di kayu salib. Etika Kristen adalah etika yang dilandaskan pada Alkitab dan meneladani hidup Kristus.

\section{Sumbangsih Etika Kristen John Frame bagi Gagasan Masyarakat}

\section{0}

Keputusan etis bijaksana dan sesuai kehendak Allah di sorga seperti apa yang Inteligensia Buatan dengan kekuatan Mahadata harus ambil pada saat Tuhan Yesus dikhianati oleh Yudas sementara Tuhan Yesus berkapasitas untuk bisa menghindar dari tindakan licik dan jahat dari Yudas dengan segala konspirasi para ahli Taurat dan orang Farisi di dalam Sanhedrin? Banyak kemungkinan yang akan bisa dimunculkan sebagai jawabannya, namun dapat dipastikan tidak mungkin akan dipilih keputusan bahwa Tuhan Yesus akan mengambil keputusan untuk naik ke kayu salib. Hal ini memaparkan kegagalan Inteligensia Buatan (AI) mendapatkan data spiritualitas dan memberikan keputusan spiritual dalam kehidupan manusia. Tidak ada Inteligensia Buatan yang mampu untuk memperhitungkan kekuatan spiritualitas di dalam setiap situasi dan dalam setiap individu yang berbeda di dalam mengambil pertimbangan dan keputusan etis yang sesuai dengan kehendak Allah.

Dari sudut pandang Kristen (Reformed), ada beberapa keterbatasan Mahadata dan Inteligensia Buatan untuk mengambil keputusan etis yang tepat:

a) Allah Bijaksana Ultimat. Inteligensia Buatan tidak dapat menggantikan Allah, karena penilai etis tertinggi bukanlah inteligensia buatan, melainkan Allah sendiri. Inteligensia Buatan pada dasarnya adalah hasil 
karya manusia berdosa, dan tidak mungkin bisa berkapasitas Allah. Allah adalah Diri-Nya Bijaksana Ultimat yang tidak mungkin digantikan oleh apapun atau siapapun di dalam melakukan keputusan etis yang benar.

b) Manusia rohani. Inteligensia Buatan tidak dapat menggantikan manusia di dalam mengambil keputusan etis, karena manusia dicipta menurut peta teladan Allah, sehingga manusia merupakan ciptaan yang bernatur rohani. Kemampuan rohani manusia memungkinkan manusia dapat merelasikan pertimbangan bijaksana situasional dengan kehendak Allah yang kekal di dalam sejarah. Inteligensia Buatan tidak berkapasitas rohani dan tidak memiliki kemampuan rohani.

c) Dunia berdosa. Alkitab menyatakan bahwa dunia ini (semua manusia) adalah dunia berdosa dan bersifat kejahatan. Akibatnya, pertimbangan manusia di dunia, termasuk para pembuat Inteligensia Buatan dan juga seluruh kesimpulan yang dikumpulkan secara induktif oleh Mahadata, adalah merupakan kumpulan data dosa yang melawan Allah dan kebenaran. Akibatnya akan muncul banyak kekacauan etis dari hasil keputusan Inteligensia Buatan yang mengandalkan Mahadata berdosa ini.

d) Pengelolaan Etis dunia milik Allah. Fakta penciptaan tidak mampu masuk di dalam pertimbangan inteligensia buatan tanpa adanya sumbangsih pemikiran Kristen di dalamnya. Pengelolaan ekonomi yang baik tidak bisa dilepaskan dari aspek etika ekonomi yang menjadi landasan pertimbangannya.

Masyarakat 5.0, membutuhkan sumbangsih etika Kristen untuk dapat memberikan kemungkinan bentuk kehidupan masyarakat yang seperti diharapkan. Peranan dari etika Reformed yang dipaparkan John Frame dapat menjadi masukan yang perlu dipertimbangkan.

\section{A. Landasan Pikir Theologis-Etis}

Seperti telah diungkap di atas Masyarakat 5.0 (Society 5.0) dimengerti sebagai masyarakat yang berupaya mengintegrasikan dunia siber dan dunia fisik untuk mencapai keseimbangan dari semua pengembangan ekonomi sambil memberikan penyelesaian terhadap masalah sosial masyarakat. ${ }^{36}$ Integrasi tinggi antara dunia siber dan dunia fisik (manusia) dalam Masyarakat 5.0 diharap tetap akan berpusat pada manusia. Dengan demikian, upaya Masyarakat 5.0 tidak boleh menurunkan apalagi meniadakan natur dan elemen dasar manusia itu sendiri. Secara umum, manusia menyadari butuhnya pertimbangan etis (baik atau jahat; benar atau salah)

36 Cabinet Office, Realizing Society 5.0 (Jepang: Cabinet Office Japan, 2019), diakses pada 29 Juli 2021, https://www.japan.go.jp/abenomics/_userdata/abenomics/pdf/society_5.0.pdf. 
dari setiap tindakan yang ia atau orang lain lakukan, khususnya terhadap sesamanya. Dalam pandangan Kristen, upaya menggarap satu masyarakat dimana natur dan elemen dasar manusia diutamakan, akan menyebabkan tuntutan pertimbangan teologis-etis tidak bisa dilepaskan dari pembentukan Masyarakat 5.0.

Frame melihat bahwa kehidupan manusia adalah kehidupan teologis-etis. Manusia adalah makhluk rohani dan karenanya pertimbangan dan pertanggungjawaban etis tidak dapat dilepaskan dari setiap pemikiran dan tindakannya.

A person can be obedient simply out of fear. But in our relationship to God, that is hardly the ideal. God wants us to obey him because we believe that his norms are right, that he is indeed the highest standard of goodness. ${ }^{37}$

Masyarakat 5.0 membutuhkan pengertian bahwa Allah itulah standar kebajikan yang akan membuat kehidupan masyarakat menjadi baik. Harapan kemanusiaan yang sejati untuk mengimplementasikan keinginan manusia tidak menjadi budak digital seperti pada Masyarakat 4.0 haruslah diisi dengan pertimbangan yang tepat dan benar di dalam pengambilan keputusan etis.

\section{B. Sumbangsih Tiga Perspektif Etika Reformed bagi Masyarakat Kristen 5.0}

Sumbangsih etika Reformed dari John M. Frame dapat diperoleh dari implementasi segitiga perspektif etika yang secara simultan mengisi harapan Masyarakat 5.0. Seorang Kristen tidak mungkin menghindar dari pengaruh Revolusi Industri 5.0 dan tentunya juga harus berupaya untuk membawa manusia memenangkan situasi tidak dicengkeram oleh terkaman kekuatan digital.

Semangat Masyarakat 5.0 perlu dihargai, namun orang Kristen harus melihat pentingnya panggilan etis. Hidup Kristen adalah hidup etis. Semua pengembangan teknologi digital tidak boleh merusak kehidupan etis orang percaya, bahkan seluruh umat manusia. Masyarakat 5.0 perlu dilengkapi kekuatan etika Kristen, akan menjadi satu pilihan yang baik untuk menjadi landasan kehidupan Kristen tetapi juga sekaligus dapat menjadi kesaksian bagi orang-orang yang belum percaya. Etika Kristen (Reformed) yang diangkat oleh John M. Frame akan menjadi elemen penting bagi pembentukan Masyarakat Kristen 5.0, yaitu:

37 John M. Frame, The Doctrine of the Christian Life, 319. 
a. Persepektif Normatif (Hidup di bawah Hukum Allah). Dalam pandangan Kristen, Masyarakat 5.0 membutuhkan topangan untuk menghidupi kehidupan kemanusiaan yang kuat dan berdignitas. Untuk itu dibutuhkan satu landasan etis yang bersifat normatif dan dapat diberlakukan kepada seluruh elemen masyarakat tersebut. Dunia digital adalah dunia teknis yang dapat digunakan untuk hal yang baik, tetapi tentu juga bisa digunakan untuk hal yang jahat. Untuk itu, pertimbangan etis sangat dibutuhkan. Tanpa prinsip yang kuat maka kemungkinan menjadi korban atau pelaku penyalahgunaan dunia digital akan sangat rawan terjadi. Disini landasan etis normatif akan menjadi timbangan untuk menentukan pilihan. Inilah yang diharapkan bisa membentuk Masyarakat Kristen 5.0.

b. Perspektif Situasional (Hidup dan berkarya di dalam dunia milik Allah). Salah satu problema serius manusia masa kini adalah hidup di era digital Revolusi Industri 4.0. Apa yang menjadi problema etis orang Kristen adalah bagaimana berhadapan dengan satu situasi yang tidak pernah terjadi 50 tahun yang lalu. Zaman ini adalah zaman media sosial. Netflix pada 9 September 2020 telah merilis satu film dokumenter, yang mewawancarai para pakar dunia media sosial, seperti ahli etika mesin dari Google, mantan engineer Facebook, presiden dari Pinteres, pendiri Center for Humane Technology, yang berjudul "Social Dilemma." ${ }^{38}$ Disitu kita menyadari bahwa hal yang sedemikian dianggap positif seperti telpon pintar yang kita gunakan, ternyata memiliki dampak sosial yang sangat berbahaya, khususnya bagi anak-anak kita. Salahkah jika orang tua tidak memberikan telpon pintar atau tablet kepada anaknya? Atau sekolah Kristen tidak seharusnya membiarkan anak-anak yang belum dewasa mengakses internet tanpa pendampingan guru secara serius? Ini adalah problema etis dimana perspektif normatif seringkali tidak cukup memadai digunakan, jika tidak disertai dengan pentingnya pertimbangan perspektif situasional. Ada pertimbangan situasi yang harus mengisi dan menjadi pertimbangan simultan keputusan etis orang percaya, yang tetap dilandaskan dan tidak meninggalkan perspektif normatif. Menghadapi tantangan Revolusi Digital diperlukan kecepatan tanggap dengan kekuatan etis yang memiliki angkur kuat, namun sekaligus bisa cukup dinamis untuk menghadapi perubahan zaman. Selama ini dunia digital dianggap akan menyelesaikan masalah manusia apabila bisa memberikan keuntungan material, mendukung efisiensi kerja, tanpa melihat aspek pertanggung jawaban mandat budaya di hadapan Tuhan dan kebenaran-Nya. Disini Frame melihat pentingnya perspektif situasional

\footnotetext{
Pandangan Jogja Com, “'The Social Dilemma' bagian 4: Kumpulan Kutipan yang Bikin Pingin Hapus Medsos," Kumparan, 1 Oktober 2020, https://kumparan.com/pandangan-jogja-com/ the-social-dilemma-bagian-4-kumpulan-kutipan-yang-bikin-pengin-hapus-medsos-1uJ201Z4MWl/4.
} 
dalam etika Kristen yang Alkitabiah. Frame mendefinisikan: "As the normative perspective focuses on God's lordship attribute of authority, the situational perspective focuses on his lordship of control. ${ }^{\prime \prime 39}$ Pengembangan Masyarakat 5.0 harus dapat menjadi berkat dan memanusiakan manusia, dimana seluruh pengembangan digital harus dipikirkan dalam kerangka hukum Allah sebagai pertanggung-jawaban di hadapan Allah. Keterlibatan orang percaya di dalam tindak digital perlu memperhatikan situasi dimana dia berada. Ia hadir sebagai pembawa mandat Tuhan, dan tidak menggunakan semua milik Tuhan (termasuk kapasitas dan talenta digital) untuk merusak nama Tuhan ataupun menggenapkan apa yang Iblis inginkan, seperti memberikan platform pengembangan dunia pornografi ataupun penipuan online. Masyarakat 5.0 akan menjadi masyarakat yang baik dan menjadi berkat apabila dapat menggunakan setiap situasi, setiap sumber daya dan kemampuan digital, sesuai dengan pertanggung-jawaban etis di hadapan Allah.

c. Perspektif Eksistensial (Hidup bertanggung jawab kepada Allah). Menggarap kehidupan di dalam dunia digital bukanlah hidup terlepas dari tanggung jawab etis di hadapan Allah secara eksistensial. Frame melihat relasi ketiga perspektif sebagai berikut: "The normative perspective can be seen as a Christian deontological ethic, the situational perspective as a Christian teleological ethic, and the existential perspective as a Christian existential ethic. ${ }^{\prime 40}$ Setiap kita akan dihakimi oleh Allah akan apa yang kita lakukan di dunia ini. Rasul Paulus memberikan pola pikir etis yang berbeda dari cara pandang Masyarakat 5.0.

"Sesuai dengan kasih karunia Allah, yang dianugerahkan kepadaku, aku sebagai seorang ahli bangunan yang cakap telah meletakkan dasar, dan orang lain membangun terus di atasnya. Tetapi tiap-tiap orang harus memperhatikan, bagaimana ia harus membangun di atasnya. Karena tidak ada seorangpun yang dapat meletakkan dasar lain dari pada dasar yang telah diletakkan, yaitu Yesus Kristus. Entahkah orang membangun di atas dasar ini dengan emas, perak, batu permata, kayu, rumput kering atau jeram, sekali kelak pekerjaan masing-masing orang akan nampak. Karena hari Tuhan akan menyatakannya, sebab ia akan nampak dengan api dan bagaimana pekerjaan masing-masing orang akan diuji oleh api itu. Jika pekerjaan yang dibangun seseorang tahan uji, ia akan mendapat upah. Jika pekerjaannya terbakar, ia akan menderita kerugian, tetapi ia sendiri akan diselamatkan, tetapi seperti dari dalam api. Tidak tahukah kamu, bahwa kamu adalah bait Allah dan bahwa Roh Allah diam di dalam kamu? Jika ada orang yang membinasakan bait Allah, maka Allah akan membinasakan dia. Sebab bait Allah adalah kudus dan bait Allah itu ialah kamu. (18) Janganlah ada orang yang menipu dirinya sendiri. Jika ada di antara kamu yang menyangka dirinya berhikmat menurut dunia ini, biarlah ia menjadi bodoh, supaya ia berhikmat. (19) Karena hikmat dunia

39 John M. Frame, The Doctrine of the Christian Life, 240.

40 John M. Frame, The Doctrine of the Christian Life, 317. 
ini adalah kebodohan bagi Allah. Sebab ada tertulis: "Ia yang menangkap orang berhikmat dalam kecerdikannya." Dan di tempat lain: "Tuhan mengetahui rancangan-rancangan orang berhikmat; sesungguhnya semuanya sia-sia belaka." (21) Karena itu janganlah ada orang yang memegahkan dirinya atas manusia, sebab segala sesuatu adalah milikmu: baik Paulus, Apolos, maupun Kefas, baik dunia, hidup, maupun mati, baik waktu sekarang, maupun waktu yang akan datang. Semuanya kamu punya. Tetapi kamu adalah milik Kristus dan Kristus adalah milik Allah." ${ }^{41}$

Paulus menekankan bahwa manusia bertanggung jawab etis di hadapan Allah. Manusia bukan otoritas tertinggi dan manusia tidak bertanggung-jawab kepada dunia digital. Data bukanlah Allah yang kepadanya kita harus menyembah dan bertanggung jawab. Hanya kepada Allah yang hidup, Allah yang adalah Hakim Ultimat kita harus mempertanggungjawabkan setiap kehidupan kita. Alkitab menyatakan bahwa tidak ada seorangpun, siapapun dia, bisa lolos dari penghakiman Allah ini. Isu etis bukanlah sekedar suatu teori obyektif, tetapi harus dihidupkan secara eksistensial di dalam panggilan setiap orang yang berbeda di dalam zaman yang berbeda dengan kondisi yang berbeda dan tugas yang berbeda pula. Dalam hal ini, Frame menekankan bahwa perspektif eksistensial akan menyadarkan orang Kristen bahwa ketaatan bukan dijalankan sekedar karena takut, tetapi karena meyakini apa yang dilakukan di hadapan Tuhan dan sesuai kehendak Tuhan itu adalah hal yang terbaik. Hanya manusia yang sudah dilahirbarukan dapat menyadari bahwa ia dicipta menurut gambar Allah dan akan dapat melihat teladan "kebaikan Allah" sebagai standar tertinggi bagi kehidupan pribadinya. ${ }^{42}$ Dunia digital tanpa kesadaran ini akan membawa manusia kepada kekacauan pertanggung jawaban etis. Kita harus menyadari ketika kita beraktivitas media sosial, ada kesadaran kesucian Allah, keadilan Allah, kemuliaan Allah, dan kebenaran Allah yang mewarnai aktivitas tersebut. Adanya kesadaran teologis-etis secara eksistensial akan menjaga aktivitas digital kita bisa memuliakan Allah dan menjadi berkat bagi orang lain. Disini semangat Masyarakat 5.0 baru mencapai apa yang diharapkan.

\section{Masyarakat Kristen 5.0 di Era Revolusi Industri 4.0}

Frame melihat bahwa pertimbangan etis orang Kristen adalah pertimbangan totalitas hidupnya. Seluruh pikiran, perasaan, pertimbangan intuisinya, dan berbagai imajinasinya adalah hal yang tidak bisa dipertentangkan, melainkan merupakan satu keutuhan dari totalitas semua itu yang membentuk

41 Korintus 3:10-23 (TB).

42 John M. Frame, The Doctrine of the Christian Life, 318 dst. 
keputusan etis seorang manusia.

It is sometimes thought that reason, emotion, conscience, imagination, will, and so forth, are more or less autonomous units, battling one another for supremacy in each human mind. But it is more scriptural to say that the whole person is the one who makes ethical decisions, and that the ethical faculties are ways of describing the person as he makes those decisions. ${ }^{43}$

Berdasarkan pengertian di atas, secara umum manusia sadar bahwa manusia tidak bisa hidup tanpa pertimbangan dan keputusan etis, termasuk tentunya masyarakat Kristen. Seharusnya sudah menjadi pemahaman umum bahwa kehidupan manusia tanpa pertimbangan moral yang agung akan menghasilkan karakteristik hidup yang rendah dan hina.

\section{A. Karakteristik Masyarakat Kristen 5.0.}

Hadir di era Revolusi Industri 4.0 tentu menyebabkan terciptanya suatu situasi kondisi dimana setiap orang Kristen (masyarakat Kristen) tidak dapat menghindar dari revolusi dan disrupsi digital. Sulit untuk orang Kristen mau hidup dengan kendaraan yang tidak memiliki elemen digital atau tidak menggunakan dompet digital atau perbankan digital, apalagi telpon pintar. Secara fakta, mayoritas orang Kristen pengguna produk digital, mulai dari menggunakan telpon pintar, media sosial, belanja online dan berbagai aktivitas lainnya. Gagasan Masyarakat Kristen 5.0 merupakan hal penting untuk membangun satu masyarakat etis yang tidak ditelan oleh disrupsi digital. Manusia harus menjadi tuan dan pengatur dunia milik Tuhan, dan tidak membiarkan dunia ini dirusak dan menjadi chaos. Gagasan Masyarakat Kristen 5.0 diperlukan di dalam menghadapi tantangan Revolusi Industri 4.0 secara holistik.

\section{B. Tanggung Jawab Etis dalam Masyakarat Kristen 5.0.}

Masyarakat Kristen 5.0 harus berpikir selangkah lebih bijaksana ketimbang Masyarakat 5.0. Problema dosa tidak bisa diselesaikan oleh Revolusi Digital. Dataisme tidak akan mampu memberikan landasan obyektif bagi keputusan etis, seperti yang dipikirkan oleh para pakar Dataisme, maupun Masyarakat 5.0. Kekuatan data dan proses Inteligensia Buatan, tidak akan memadai di dalam membangun keputusan etis, karena tidak akan mampu mencapai tuntutan etis dalam perspektif normatif, situasional, dan eksistensial di hadapan Allah. Orang percaya sadar bahwa hanya mereka yang sudah dilahirkan kembali yang dapat membangun relasi kovenantal dengan Allah, bisa mengerti beretika menurut kehendak dan wahyu Tuhan.

43 John M. Frame, The Doctrine of the Christian Life, 361. 
In The Doctrine of the Knowledge of God, I argued that knowing God, in Scripture, is not merely learning additional facts or becoming familiar with an additional object. Rather, since God is a person, to know him is to enter into a personal relationship with him. His relationship to us is covenantal, for he is Lord. Therefore, to know him is to become his covenant servant. ${ }^{44}$

Mereka yang belum hidup baru, tidak memiliki pertimbangan tanggung jawab etis di hadapan Allah dan firman-Nya. Keberadaan orang Kristen menjadi sangat signifikan, karena akan memberikan teladan bagaimana hidup dengan tanggung jawab etis di hadapan Allah, yang melampaui standar etika sekuler manusia.

\section{Konsep Kesucian di dalam Etika Masyarakat Kristen 5.0}

Salah satu masalah serius di dalam pengembangan IR 4.0 adalah masalah etika perilaku manusia yang amoral. Manusia kehilangan sifat moral yang paling penting yaitu aspek kesucian hidup. Hidup yang bersih bukan hanya secara tampilan, tetapi kebersihan hati, motivasi yang murni, dan ketidak-relaan merusak kehidupan. Di dalam argumentasi kedua, Frame menegaskan bahwa Tuhan itu "supremely holy person," 45 sehingga orang Kristen haruslah menjadi orang yang disucikan, dan mau berjuang untuk kemudian hidup suci. Frame meletakkan ini di dalam konteks kedaulatan kasih Allah. Kita umat Allah adalah umat yang disebut "bangsa yang kudus," umat kepunyaan Allah sendiri. ${ }^{46}$ "It is amazing that the same Lord whose holiness separates us from him also reaches out to draw us into the circle of his holiness - indeed, to make us his holy people."

Status sebagai umat kudus Allah, mengharuskan Masyarakat Kristen 5.0 tidak boleh cemar dan kehilangan kekudusannya sebagai umat Allah di tengah-tengah dunia IR 4.0. Frame mengatakan: "It is not appropriate to set our hearts on things that are doomed to be burnt up. Holiness and righteousness, however, last forever, and are therefore worth pursuing. "48 Perjuangan terberat masyarakat berhadapan dengan tantangan IR 4.0 justru salah satunya adalah perjuangan kehidupan yang suci dan takut akan Tuhan. Masyarakat yang terpapar IR 4.0 berkecederungan menyerah di bawah kekuatan Dataisme dan Intelligensia Buatan, yang kemudian hidup pragmatis terhadap isuisu moral. Masyarakat Kristen 5.0 terpanggil untuk dapat menggunakan kekuatan Intelligensia Buatan dan Mahadata bagi kegenapan kehidupan yang berkenan dan menjalankan kehendak Allah.

44 John M. Frame, The Doctrine of the Christian Life, 350-351.

45 John M. Frame, The Doctrine of the Christian Life, 20.

${ }^{4}$ Ulangan 14:2 (TB); 1Petrus 2:9 (TB)

47 John M. Frame, The Doctrine of the Christian Life, 21.

8 John M. Frame, The Doctrine of the Christian Life, 282. 


\section{Penutup dan Kesimpulan}

Hadirnya Revolusi Industri 4.0 (Industrial Revolution 4.0) telah menuntut setiap orang di zaman ini untuk melakukan langkah-langkah antisipatif yang jitu dan bijak. Mereka yang gagal bergerak dinamis akan tertinggal, mengalami banyak tekanan dan kerugian.

Disrupsi Revolusi Industri 4.0 ini disadari telah menimbulkan berbagai masalah, khususnya ancaman bagaimana manusia akan menjadi akibat dan alat dari dunia digital. Masyarakat 5.0 (Society 5.0) yang digagas oleh Kabinet Kementerian Jepang telah berusaha untuk mengantisipasi masalah ini. Diupayakan agar Revolusi Industri 4.0 tetap berpusat demi kepentingan manusia, bukan manusia menjadi alat teknologi.

Namun, gagasan Masyarakat 5.0 dalam pandangan Kristen mengalami lubang yang cukup signifikan di dalam aspek etika. Ketika Masyarakat 5.0 ini menggunakan Revolusi Digital demi kebaikan dan berpusat pada kesejahteraan manusia, maka tidak bisa tidak seharusnya aspek etika merupakan bagian yang tak terpisahkan dalam gagasan ini. Namun, pada faktanya Masyarakat 5.0 sama sekali tidak menyentuh aspek etika, karena diasumsikan dengan kekuatan Inteligensia Buatan (Artificial Intelligence), maka semua problema etis akan diambil alih oleh mesin dan kekuatan data. Ini merupakan asumsi dari Agama Data (Dataisme) yang tidak dapat dipertanggung jawabkan.

Dalam pandangan Kristen, siapapun yang tidak lahir baru tidak mungkin bisa beretika dengan benar. Kehidupan masyarakat yang berdosa tidak akan mencapai kondisi masyarakat yang baik dan sejahtera. Etika masyarakat yang membentuk kemungkinan terciptanya masyarakat yang baik dan sejahtera terjadi apabila komunitas masyarakat tersebut adalah komunitas masyarakat yang bisa hidup bersama dalam tatanan atribusi yang Allah derivasikan dan menjalankan kehendak Allah. Oleh karena itu, Masyarakat 5.0 tanpa etika Alkitab tidak mungkin bisa mencapai harapan yang diinginkan.

Orang Kristen yang hidup di era Revolusi Industri 4.0 tentu sejalan dengan harapan Masyarakat 5.0 untuk bisa hidup di dalam dunia digital tanpa perlu dikuasai oleh kekuatan data dan inteligensia buatan, tetapi bisa tetap mengutamakan manusia dan menggunakan semua sarana dan sumber daya yang Allah beri untuk menjalankan mandat menyejahterakan manusia. Celah yang belum terlihat oleh Masyarakat 5.0 yaitu orang percaya perlu mempertanggung jawabkan semua tindak etisnya untuk memuliakan Allah dan menjalankan firman Allah. Orang Kristen membutuhkan landasan etis yang tepat bagi hidup dan keputusannya di tengah era dunia digital ini. Inilah yang menjadi harapan Masyarakat Kristen 5.0. 
John M. Frame, seorang teolog Reformed melihat bahwa etika Kristen seharusnya mampu untuk bisa memberikan landasan kokoh dan sekaligus mampu berhadapan dengan dinamika yang begitu disruptif dari Revolusi Industri 4.0 ini. Di dalam berpikir dan bertindak, seorang Kristen harus mempertimbangkan tiga perspetif sekaligus secara simultan, yaitu: 1) bagaimana ia bisa hidup menjalankan hukum-hukum Allah (perspektif normatif), 2) di tengah-tengah dunia milik Allah yang tentunya harus digarap seturut situasi dan kondisi dimana ia hidup (perspektif situasional), dan secara motivasi dan pribadi bertanggung jawab kepada Allah dimana tindakannya dilakukan demi untuk memuliakan Allah dan menjadi berkat bagi sesama (perspektif eksistensial). Inilah yang diharapkan dijalankan oleh Masyarakat Kristen 5.0.

\section{Bibliografi Selektif}

Alexander, Larry, dan Michael Moore. "Deontological Ethics". Stanford Encyclopedia of Philosophy. Stanford University. Artikel diterbitkan pada 21 November 2007; modifikasi terakhir pada 30 Oktober 2020. https:// plato.stanford.edu/entries/ethics-deontological/.

Bavinck, Herman. Reformed Dogmatics (4 vols). Grand Rapids, Mi.: Baker Academie, 2008.

Bongomin, Ocident, Aregawi Yemane, Brendah Kembabazi, Clement Malanda, Mwewa Chikonkolo Mwape, Nonsikelelo Sheron Mpofu, dan Dan Tigalana, "Industry 4.0 Disruption and Its Neologisms in Major Industrial Sectors: A State of the Art" Journal of Engineering vol. 2020, Art.ID 8090521 (2020). https://doi.org/10.1155/2020/8090521.

Cabinet Office. Realizing Society 5.0. Jepang: Cabinet Office Japan, 2019. Diunduh pada 29 Juli 2021. https://www.japan.go.jp/ abenomics/_userdata/abenomics/pdf/society_5.0.pdf.

Cabinet Office. "Society 5.0". Diakses pada 29 Juli 2021. https://www8.cao. go.jp/cstp/ english/society5_0/index.html.

Driver, Julia. "History of Utilitarianism". Stanford Encyclopedia of Philosophy. Standford University. Artikel diterbitkan pada 27 Maret 2009; modi-

fikasi terakhir pada 22 September 2014. https://plato.stanford.edu/ entries/utilitarianism-history.

Frame, John M.. The Doctrine of the Christian Life. Phillipsburg, NJ.:

Presbyterian and Reformed Publ. (P\&R), 2008.

Haqqi, Halifa, dan Hasna Wijayati. Revolusi Industri 4.0 di tengah Society 5.0.

Yogyakarta: Penerbit Quadrant, 2019.

Harari, Yuval Noah. Sapiens. New York: HarperColllins, 2015. Ebook.

Harari, Yuval Noah. Homo Deus. New York: HarperCollins, 2017. EBook. 
I-scoop. "From Industry 4.0 to Society 5.0: the big societal transformation plan of Japan". Diakses pada 29 Juli 2021. https://www.i-scoop.eu/ industry-4-0/society-5-0.

Keidanren. Toward Realization of the New Economy and Society. Jepang: Keidanren-Japan Business Federation, 19 April 2016. Diunduh pada 29 Juli 2019. http://www.keidanren. or.jp/en/policy/2016/029_outline.pdf.

Kraut, Richard. "Aristotle's Ethics". Stanford Encyclopedia of Philosophy. Stanford University. Artikel diterbitkan pada 1 Mei 2001; modifikasi terakhir pada 15 Juni 2018. https://plato.stanford.edu/entries/ aristotle-ethics/.

McCartney, Steve, dan Rick Parent. Ethics in Law Enforcement. Victoria, B.C.: BC Campus, 2015. http://opentextbc.ca/ethicsinlawenforcement/.

Nizar. "Hubungan Etika dan Agama dalam Kehidupan Sosial". Jurnal Arajang, vol. 1, no. 1, 2017, pp. 27-35. https://media.neliti.com/ media/publications/231177-hubungan-etika-dan-agama-dalam-kehidupan-b0d43e84.pdf.

Pandangan Jogja Com. "'The Social Dilemma' bagian 4: Kumpulan Kutipan yang Bikin Pingin Hapus Medsos". Kumparan, 1 Oktober 2020. https:// kumparan.com/pandangan-jogja-com/the-social-dilemma-bagian-4kumpulan-kutipan-yang-bikin-pengin-hapus-medsos-1uJ201Z4MWl/4.

Rosenthal, Sandra B. "Situation ethics". Encyclopedia Britannica. Artikel diterbitkan pada 26 Mei 2017; modifikasi terakhir pada 8 Januari 2019. https://www.britannica.com/topic/ situation-ethics.

Schwab, Klaus. The Fourth Industrial Revolution. New York: Penguin Random House, 2017.

Sima, Violeta, Ileana G. Gheorghe, Jonel Subi'c, dan Dumitru Nancu. "Influences of the Industry 4.0 Revolution on the Human Capital Development and Consumer Behavior: A Systematic Review". Sustainability 12, no. 10 (14 Mei 2020): 4035. https://doi.org/ 10.3390/ su12104035.

Sudibyo, Agus. "Menggugat Monopoli Platform Digital". Kompas. id, 08 Juli 2020. https://www.kompas.id/baca/opini/2021/07/08/ menggugat-monopoli-platform-digital.

Sudibyo, Agus. "Mempersoalkan Imparsialitas Platform Digital". Kompas. id, 23 September 2021. https://www.kompas.id/baca/opini/2021/09/23/ demitologi-imparsialitas-platform-digital. 